\title{
Tatárjuharos-tölgyesek (Aceri tatarici-Quercetum pubescentis-roboris Zólyomi 1957) az Észak-Mezőföldön és a Zámolyi-medence környékén
}

\author{
HORVÁTH András ${ }^{1}$, KEVEY Balázs ${ }^{2 *}$, LENDVAI Gábor ${ }^{3}$, SIMON György ${ }^{4}$ és \\ SONNEVEND Imre \\ ${ }^{1}$ MTA Ökológiai Kutatóközpont, Ökológiai és Botanikai Intézet, \\ 2163 Vácrátót, Alkotmány u. 2-4.; horvath.andras@okologia.mta.hu \\ ${ }^{2}$ Pécsi Tudományegyetem, Ökológiai Tanszék, \\ 7624 Pécs, Ifjúság u. 6.; keveyb@ttk.pte.hu \\ 37000 Sárbogárd, Ady E. út 162.; gaborlendvai@hotmail.com \\ ${ }^{4} 8000$ Székesfehérvár, Széchenyi u. 35.; tepuisimon@gmail.com \\ ${ }^{5} 8200$ Veszprém, Lóczi L. u. 5/G.; sonnevend.imre@chello.hu
}

Elfogadva: 2017. április 20.

Kulcsszavak: Alföld, erdőssztyep löszön, szüntaxonómia, sokváltozós összehasonlítás.

Összefoglalás: E dolgozatban, a Mezőföld löszön kialakult erdőssztyep-tölgyeseit bemutató sorozatunk harmadik részeként, most a Mezőföld északi peremvidékén és az azzal szomszédos területen megtalált nyílt vagy félig nyílt lombkoronaszintủ állományokat vizsgáltuk abból a célból, hogy elterjedésüket, szüntaxonómiai helyzetüket, növényföldrajzi jellemzőiket és állapotukat meghatározzuk. Az Észak-Mezőföldön található fásításokat és erdőmaradványokat Nádasdladánytól Gyúróig áttekintve kilenc helyszínen találtunk természetes eredetűnek ítélt nyílt erdőssztyep állományokat, amelyekből összesen 20 fitoszociológiai mintát vettünk. A mintákat hagyományos és sokváltozós módszerekkel elemeztük. Az észak-mezőföldi minták a mintánkénti fajszám, a lombkoronát alkotó fajok mintánkénti száma tekintetében lényegében nem különböztek a mezőföldi mintáktól. Szintén nagyfokú hasonlóság mutatkozott a meghatározó szüntaxonok karakterfajainak csoportrészesedésében a délkelet-európai bokorerdők (Orno-Cotinion s. 1.) fajainak kivételével, amely számottevően magasabb, mint a Mezőföld esetében. A flóraelemek csoportrészesedéseinek eloszlása és rangsorrendje nagymértékben hasonló, de az észak-mezőföldi mintákban a szubmediterrán s. l. és közép-európai fajok csoportrészesedése magasabb, az eurázsiai és adventív fajoké pedig alacsonyabb a mezőföldi mintákhoz képest. A sokváltozós csoportosítás során élesen elkülönültek a Vértes melegkedvelő tölgyeseitől, és a Mezőföld és a Velencei-hegység mintái között foglaltak helyet.

Az eredmények alapján megállapítható, hogy a vizsgált területen található molyhos tölgyes állományok a 18. század végén megtalálható erdők maradványainak tekinthetők, részben már extrazonális helyzetben. Jellemzöik alapján a tatárjuharos-tölgyesekkel (Aceri tatarici-Quercetum pubescentis-roboris) azonosíthatók, de e társulásnak már egy erősen szubmediterrán jellegủ változatát képviselik. Termőhelyi viszonyaikban és faji összetételükben kifejezetten átmeneti jellegủek az alföld erdőssztyep-erdői és a középhegységek molyhos tölgyesei között.

\footnotetext{
* Levelező szerző.
} 


\section{Bevezetés}

Az Alföld erdőssztyep-maradványainak felkutatása és részletes vizsgálata európai viszonylatban is kiemelt jelentőségű. Az erdőspusztai életközösség ugyanis mással nem pótolható információt hordoz a vegetáció elmúlt 12 ezer évi történetéről, az erdőspusztai fajok biogeográfiai jellemzőiről és kapcsolatairól, és a természetes ökológiai folyamatokról és szabályozási mechanizmusokról (Fekete és VARGa 1999). Az erdőssztyep-maradványok egyúttal őrzői a Pannon Biogeográfiai Régió kiemelkedő biológiai és ezen belül genetikai sokféleségének, és mint a természetes életközösségek általában, nélkülözhetetlen ökoszisztéma szolgáltatásokat nyújtanak, melyek közt jelentős az esztétikai és jóléti szerepük (HARAszThy 2000). Mindezek miatt, továbbá rendkívüli ritkaságuk következtében megőrzésük és lehetőség szerinti rekonstrukciójuk elsőrendű feladata kéne, hogy legyen a hazai természetvédelem szerveinek és szervezeteinek. Ahhoz azonban, hogy ezt a feladatot sikeresen végre lehessen hajtani, szükség van a ma még lappangó erdőssztyep-maradványok felkutatására és számba vételére, állapotuk tudományos igényü felmérésére, valamint legfőbb biológiai (ökológiai, chorológiai, populációbiológiai, genetikai, ökofiziológiai) jellemzőik és az esetleg fennálló regionális eltérések meghatározására.

A magyarországi, löszön fennmaradt erdőssztyep-erdők tudományos vizsgálatára először az ötvenes évek közepétől kezdődően Zólyomi Bálint vezetésével került sor (összefoglalását lásd ZóLYOMI et al. 2013). E munka elsősorban a zonális erdőssztyep-vegetáció közösségi szintű, társulástani és növényföldrajzi jellemzőinek feltárására irányult (ZóLYOMI 1959). Az akkortájt ismert és fellelt erdőmaradványok előfordulási helyei miatt a kutatások szinte kizárólag az Alföld és a középhegységek érintkezési területére korlátozódtak. Az akkor megszerzett ismeretek és eredmények szolgáltak alapul az Alföld löszön kialakult erdőspusztai erdőknek társulástani-növényföldrajzi rekonstruálásához és fitoszociológiai osztályozásához (Zólyomi 1957, 1989). Időközben, részint a hazai élőhelytérképezési program keretében (BöLÖNI ET AL. 2008) számos olyan molyhos tölgyeket tartalmazó állománytöredék és maradvány került elő, elsősorban a Mezőföldön és környékén, amelyek feltételezhetően ugyanezekhez a sztyeperdőkhöz sorolhatók.

A Mezőföld erdőssztyep-vegetációja a domborzat kínálta adottságok következtében még több helyen, bár erősen fragmentált és izolált formában fennmaradt. E maradványok kisebb részét teszik ki erdők, amelyek számottevő hányada a tájegység északi és északnyugati peremvidékén, részben már a szomszédos dombsági területeken (pl. Velencei-hegység, lásd FEKETE 1955, LENDVAI et al. 2014b) fordul elö. Ezek egy töredékét már ZólYOMI is tanulmányozta (ZóLYOMI 1957, 1958). A maradványok másik része a Mezőföld belső területein, illetve a Tolnai-dombság északkeleti peremén található. A maradványok ilyen térbeli el- 
helyezkedése és elegendően nagy száma lehetőséget adott arra, hogy a Mezőföld különböző részein csoportosuló állományokat egymástól elkülönítve vizsgáljuk, és az eddigieknél sokkal finomabb térléptékủ elemzést végezzünk abból a célból, hogy az állományok mai állapotát rögzítsük, a mezőföldi sztyeperdők növényföldrajzi sajátosságait részletesen megismerjük, és az alföldi löszvegetáció máig elfogadott Zólyomi-féle csoportosításának érvényességét ellenőrizzük. Eddigi eredményeinket két részre, a Mezőföld belső területére, valamint a tájegységet északról határoló Velencei-hegységre bontva adtuk közre. E dolgozatunkban a sorozat folytatásaként most a Mezőföld északi peremvidékén, az Észak-Mezőföldön talált sztyeperdő jellegủ állományok vizsgálatának eredményeit foglaljuk össze.

Földrajzi helyzetüknél fogva e maradványok köztes helyet foglalnak el a Dunántúli-középhegység déli lejtőinek szubmediterrán jellegü erdői és az Alföld erdőssztyepje között. Ráadásul a táj és vele a vegetáció éppen az Észak-Mezőföld területén vált át fokozatosan egy egyre mozgalmasabb és erdősültebb dombvidékbe, ahol a középhegység és az Alföld határai elmosódottabbak. Az Észak-Mezőföld ekként egy olyan jellegü terület, ahol kétféle növényzettípus, az erdőspuszta kontinentális és a középhegység európai-szubmediterrán növényzete, várhatóan keveredik. E terület átmeneti jellegét BARINA (2004) florisztikai alapokon elemezte.

Munkánk során fó szempont volt az, hogy az elemzések és a kapott eredmények összevethetők legyenek a tájegység egyéb részéről kapott eredményekkel. Alapvető kérdéseink ugyanazok voltak, mint amelyeket a már közreadott korábbi közleményeinkben is megfogalmaztunk, nevezetesen, hogy elöfordulnak-e és ha igen, mi az elterjedésük a tatárjuharos-tölgyeseknek ezen a területen, miben és milyen mértékben hasonlítanak a szomszédos területek tatárjuharos-tölgyeseihez, és milyen mértékben mutatható ki bennük szubmediterrán jelleg.

\section{Anyag és módszer}

Vizsgálatunk célja a középhegységhez térben közeli és így vélhetőleg azzal növényföldrajzi kapcsolatban álló sztyeperdők feltérképezése és elemzése volt. Mivel semmiféle objektív a priori kritérium nem állt rendelkezésünkre a vizsgálati terület lehatárolását illetően, ezért szubjektív módon Észak-Mezőföldnek tekintettük a Mezőföldnek az M7-es autópályától északra elterülő részét. Ez nyugaton az M7-es, a Balaton és a csóri Sárrét által közrefogott területet, középen a Zámolyitáblát, keleten pedig a nagyjából az M7-es, Gyúró, Alcsút, Vértesacsa, Pázmánd által közrefogott vidéket foglalja magában. Utóbbi terület délebbi részei még biztosan a Mezőföldhöz sorolandóak, míg nagyjából a Vál-Gyúró vonaltól északra a táj egyre inkább dombvidéki jellegü, és a kemény alapkőzet is egyre gyakrabban a felszínre bukkan, így ez valódi átmeneti terület a középhegység felé. A terület egy egységként való kezelését a középhegységhez való közelsége indokolja. 
Tatárjuharos-tölgyesek előfordulására ezen a területen elsőként SoNNEVEND (2001) hívta fel a figyelmet. Ezt követően, 2003 és 2010 között alaposan bejártuk a táj maradványerdeit, melyeket egyebek között az 1. Katonai Felmérés térképeinek segítségével kerestünk meg. Bejártuk a Székesfehérvártól északra eső Zámolyitábla völgyeit (Csapás-völgy, Nagy-völgy, Rác-völgy, Tikmony-völgy) és peremeit, továbbá Vál és Gyúró környékének néhány erdőjét (Váli-erdő, Vérti-erdő, Annamária major). Különös figyelmet fordítottunk a területen található völgyek peremein és oldalain található faállományokra, amelyekben néha zárványszerűen találtunk nyílt erdőssztyep-maradvány foltokat. Felkerestük a Zólyomi által egykor vizsgált Alcsút feletti Csaplári-erdőt (lásd Zólyomi et al. 2013), és jártunk a Kőszárhegy melletti Szár-hegyen is, ahonnan korábban molyhos tölgyesek előfordulását jelezték (BAUER és Somlyay 2007). A megvizsgált helyek közül kilencben találtunk nyílt vagy félig nyílt lombkoronájú, erdőssztyep megjelenésű állományokat, amelyek rendszerint kicsiny kiterjedésűek, és többségük a változatos domborzattal rendelkező lösztáblák ormóin, élein és letörésein találhatók 175-225 m tengerszint feletti magasságban. Részben plató helyzetben, részben pedig enyhe (5-10 fok), vagy meredek (25-40 fok) lejtőkön fordultak elő. A talajképző alapkőzet legtöbbször vastag lösz, esetenként mészkőre települt elvékonyodó löszlepel volt.

Az elemzésre alkalmas méretű állományokban összesen 20 társulástani felvételt készítettünk. A felvételek a Zürich-Montpellier növénycönológiai iskola (BECKING 1957; BRAUN-BLANQUET 1964) hagyományos kvadrát-módszerével készültek. A mintavételi terület kijelölése során elsősorban az állomány nyílt vagy félig nyílt jellegére voltunk tekintettel. Ahol az erdő nagyobb tisztásokkal érintkezett, ott az erdő szélét és a gyep lombkorona alatti részét is a minta részének tekintettük. A mintaterület mérete 800 és 1200 négyzetméter között változott az állomány méretétől függően. A mintavételt évente két alkalommal, tavasz elején (április második felében) és nyár elején (június közepén) végeztük. Az adatok alapján meghatároztuk a minták különböző paramétereit, illetve a konstancia osztályok eloszlását valamint a karakterfajok és flóraelemtípusok gyakoriságát. A minták táblázatba rendezése és a karakterfajok valamint flóraelemtípusok csoportrészesedésének és csoporttömegének kiszámítása az „NS” számítógépes programcsomaggal (KEVEY és HIRMANN 2002) történt.

A vizsgált állományok szüntaxonómiai besorolását részben a karakterfajok csoportrészesedéseinek értékei és eloszlásai, részben pedig sokváltozós csoportosítás alapján végeztük el. A sokváltozós csoportosítás célja a minták florisztikai összetételben mutatkozó hasonlóságának kimutatása volt. A sokváltozós csoportosítást kétféle módszerrel, cluster-elemzéssel és főkoordináta elemzéssel hajtottuk végre. Az elemzéseket a célnak megfelelően bináris adatokon végeztük, ahol az egyes felvételekben csupán a jelenlét-hiány adatok szerepeltek. A cluster-elemzésnél az általunk választott algoritmus a korábbi dolgozatainkban is következetesen alkalma- 
zott csoportátlag-módszer volt. Távolsági indexként mindkét módszernél a BaroniUrbani és Buser indexet használtuk. Hangsúlyozzuk, hogy az ekként kapott hasonlósági struktúra csupán egyik, de nem kizárólagos alapja a minták szüntaxonómiai megítélésének, amiben még további szempontok (pl. karakterfajok aránya, az állomány térbeli szerkezete) is lényeges szerepet kapnak.

Az elemzésekbe bevontuk a Mezőföldről és a Velencei-hegységből származó, korábban már elemzett mintákat. A szüntaxonómiai értékeléshez a tatárjuharostölgyesektől egyértelműen elkülönülő, de ahhoz mégis több tekintetben is közelálló társulás, a melegkedvelö tölgyes (Vicio sparsiflorae-Quercetum pubescentis) vértesi állományaiból származó tíz mintát (IsÉPY 1970) is felhasználtunk. A sokváltozós elemzéseket a Syn-Tax 2000 program (PoDANI 2001) segítségével végeztük.

A fajok esetében KIRÁly (2009), a társulásoknál pedig BORHIDI és KEVEY (1996), BoRHIDI (2003), ill. KeVEy (2008) nevezéktanát követjük. A társulástani és a karakterfaj-statisztikai táblázatok felépítése Soó (1980) cönológiai rendszerére épül, amit az újabb eredményeknek megfelelően (OBERDORFER 1992; MuCina et al. 1993; BoRHIDI 2003; Kevey 2008) módosítottunk. A növények cönoszisztematikai besorolásánál szintén elsősorban Soó (1964, 1966, 1968, 1970, 1973, 1980) munkáira támaszkodtunk, amit azonban az újabb kutatási eredmények (vö. BORHIDI 1993, 1995; HoRVÁTH et al. 1995) és saját terepen szerzett tapasztalataink tükrében számos helyen finomítani, illetve módosítani kellett.

A fajok elterjedési típusának (flóraelemtípus) meghatározásához számos forrásra hagyatkoztunk, mivel a rendelkezésre álló hazai adatbázisok és korábbi dolgozatok számos esetben hiányosak vagy pontatlanok. Ezért a fajok besorolásához Soó (1962) areatípusait használtuk fel, a fajok elterjedésének pontos meghatározásához pedig különböző flóraműveket és fitoszociológiai tárgyú munkát (Tutin et al. 1964-1980, Siskin és Bobrov 1933-1964, Grubov 2001, Savulescu és Nyárády 1952-1976, Simon 1994, Soó 1964-1980, Horváth et al. 1995, LaVrenko 1970, LaVrenko et al. 1991, Didukh 2009), valamint saját terepi ismereteinket használtuk.

\section{Eredmények}

\section{Elterjedés és fiziognómia}

A Mezőföld északi peremvidékén és a Zámolyi-medence környékén található és a korabeli térképek tanúsága szerint folyamatos erdőborítású erdőtömbök jelentős részében (Füle: Szentmártoni-erdő; Jenő: Vadaskerti-erdő; Ősi: Ösi-erdő; Vál: Váli-erdő, Mária-Annapusztai-erdő) nem sikerült azonosítani erdőssztyeptölgyes jellegű állományokat. A Vál melletti Váli-erdő és az Alcsúttól keletre levő Vérti-erdő bekerített tömbjeiben a túltartott vadállomány az aljnövényzetet a felismerhetetlenségig átalakította, elgyomosította, az erdőgazdálkodás során pedig 
a fafaj-összetételt a cseresek irányába tolták el. Valószínűleg a Füle közelében levő Szentmártoni-erdőben és Kölesteleki-erdőben is az intenzív erdőgazdálkodásnak köszönhető az egysíkú, zömmel csertölgyre korlátozódó fafaj-összetétel, a homogén szerkezet és az egynemü korösszetétel. Ezeken a területeken, ha valaha volt is erdőspusztai vegetáció, az mára megsemmisült.

Jellegzetes, erdőssztyep jellegủ állományokat találtunk viszont Nádasdladánytól Gyúróig kilenc helyszínen, így a Nádasdladány melletti Kasza-völgyi erdőben (SoNNEvend 2001) a Kőszárhegy melletti Szár-hegyen, a Székesfehérvártól északra elterülő Zámolyi-táblán (Székesfehérvár: Rác-völgy; Pátka: Tikmony-völgy, Máriamajori-erdő, Nagy-völgy; Zámoly: Csapás-völgy), Alcsútnál a Csaplári-erdőben, valamint Gyúrónál a Vérti-erdő déli peremének közelében. Ezek az állományok többnyire zárt tölgyesek közé ágyazva fordultak elö, leggyakrabban letörések peremein és meredekebb lejtők felső részén. Két helyszínen a vizsgált állományok vagy mezőgazdasági területek között, szigetszerủen (Székesfehérvár: Rác-völgy), vagy egy nagyobb erdőtömb szomszédságában, de attól elszigetelten (Gyúró: Vérti-erdő déli pereméhez közel) fordultak elő. E két kivételen kívül mindegyik lelőhely ott található, ahol már az 1. Katonai Felmérés térképszelvényei is erdőt jeleznek (1. ábra) és az erdőborítás valószínűleg azóta is folyamatos. A Székesfehérvár melletti Rác-völgyben viszont már 1783-ban sem volt erdő, míg Gyúrónál a vizsgált helyszíntől mintegy 600 méterre még a 19. század második felében is volt erdő, ami csak ezt követően semmisült meg.

Az állományok kitettségében és termőhelyi viszonyaiban nagyfokú változatosság volt megfigyelhető. Bár többségükben meredekebb löszletörések peremeinél vagy oldalakon fordultak elő, voltak állományok, amelyek enyhe északkeleti lejtőn (Szár-hegy) helyezkedtek el. Termőhelyeiken a talaj gyakran erősebben erodált vagy a kemény alapkőzet jelenléte miatt viszonylag sekély volt.

Megjelenését és faállományát tekintve a rác-völgyi és gyúrói állomány szintén jelentősen eltért a többitől. Gyúrónál az állomány egy félüde löszgyeppel borított lejtő beerdősödésének képét mutatta, ahol néhány igen idős, egymástól távol álló hagyásfa mellett számos fiatal, 1-3 m magas tölgyújulat, erőteljes cserjefoltok és a korábbi gyep folt maradványaiként nyílt tisztások alkották a vegetációt. A Rác-völgyben a völgy északra néző oldalát magasra nőtt cserjék borították, és ebből a szintből emelkedtek ki az elszórtan álló akácok, mezei szilek és vadkörték. Itt teljes mértékben hiányoztak a tölgy fajok, miközben mind a cserjék, mind pedig a lágyszárúak tekintetében igen gazdag az erdőspusztai vegetáció.

A vizsgált állományok felső lombkoronaszintje az állomány korától függően 12-17 méter magasságot ér el, nyílt (25-40\%), vagy közepesen záródó (5065\%). A fák jellemzően alacsonyan elágazók, gyakran görbe törzsűek. Az alsó lombkoronaszint gyér vagy közepes (15-40\%) borítású, magassága 7-12 m. Az 1-3 méter magas cserjeszint borítása tág határok (25-80\%) között változik, ami 
valószínűleg erdészeti beavatkozással hozható összefüggésbe. Részben a lombkoronaszint fáinak fiatal egyedei képezik (Acer campestre, Fraxinus ornus, Pyrus pyraster, Quercus cerris, Q. pubescens, Ulmus minor). Az alsó cserjeszint (újulat) borítása $1-30 \%$. A gyepszint borítása igen változó (20-90\%), s viszonylag sok magas állandóságú (K IV-V) faja van. Az állományokban kora tavaszi aszpektus csak kismértékben fejlödött ki, fajainak száma és tömegessége is változó, általában alacsony volt. A mintaterületeken belül jellemző a kisebb-nagyobb tisztások jelenléte, ahol sem fák sem cserjék nem gátolják a fény lehatolását a talajszintig.

\section{Sokféleség és faji összetétel}

A minták átlagos fajszáma 93,9 (10,01) faj, azonban a mintánkénti teljes fajszám 56 (Pátka: Nagy-völgy) és 128 (Székesfehérvár: Rác-völgy és Tikmony-völgy) faj között változik. A fafajok átlagos mintánkénti száma 6,6 (2,05) faj. A hazai tölgyek közül a leggyakoribb fajok a Q. pubescens és a Q. cerris voltak, míg a leginkább

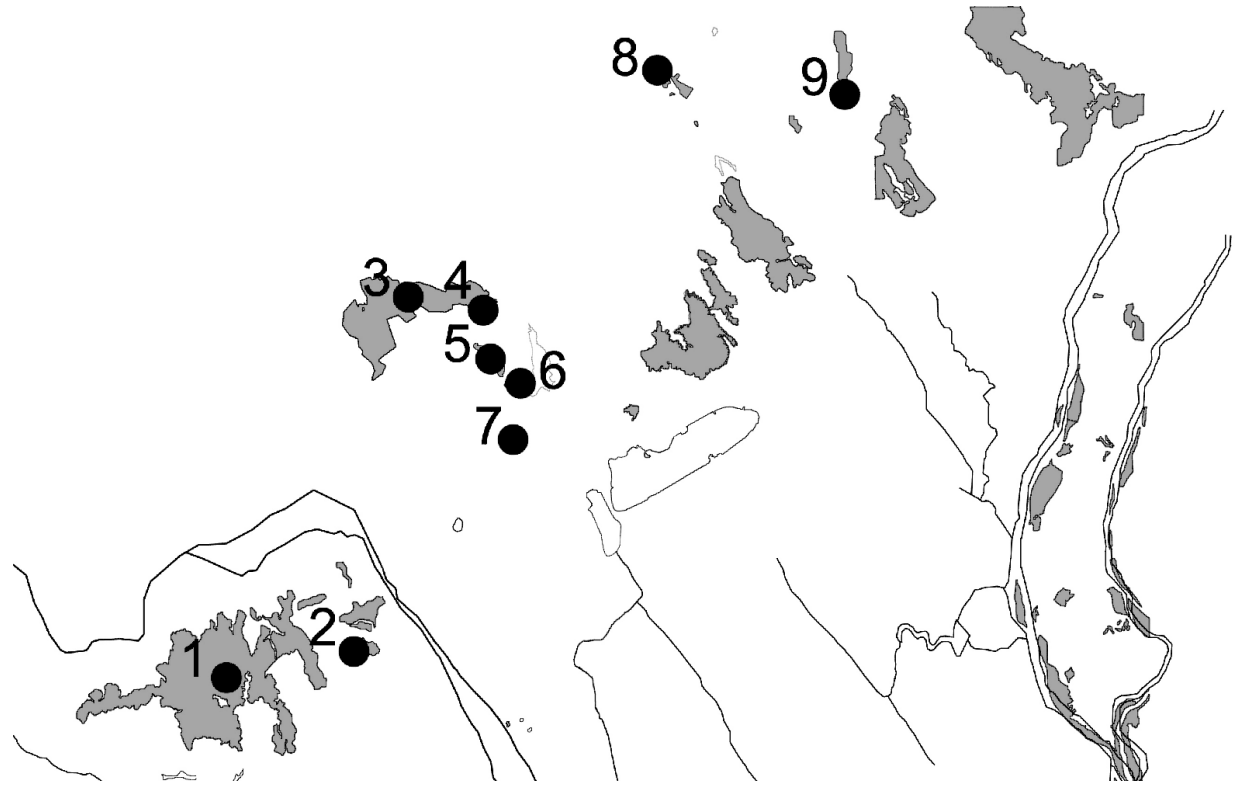

1. ábra. A mintavételek helyei (pontok) az Észak-Mezőföld 18. század végi erdőinek elterjedésével (az 1. Katonai Felmérés térképei nyomán). 1: Nádasdladány: Kasza-völgy. 2: Szár-hegy. 3: Zámoly: Csapás-völgy. 4: Pátka: Tikmony-völgy, 5: Pátka: Máriamajori-erdő, 6: Pátka: Nagy-völgy, 7: Székesfehérvár: Rác-völgy. 8: Alcsút: Csaplári-erdő. 9: Gyúró: Vérti-erdő.

Fig. 1. Sampling locations with the underlying distribution of forested areas at the end of the 18th century in the Northern Mezőföld (after the maps of the First Military Survey). 1: Nádasdladány: Kasza-völgy. 2: Szár-hegy. 3: Zámoly: Csapás-völgy. 4: Pátka: Tikmony-völgy, 5: Pátka: Máriamajori-erdő, 6: Pátka: Nagy-völgy, 7: Székesfehérvár: Rác-völgy. 8: Alcsút: Csaplári-erdő. 9: Gyúró: Vérti-erdő. 
mezofil jellegű $Q$. robur csupán egyetlen felvételben szerepelt. A cserjék átlagos fajszáma 12,0 (1,08), a lágyszárúaké pedig 75,4 (9,92) faj. Ezek az értékek nem térnek el szignifikánsan a Mezőföldről származó minták megfelelő értékeitől (1. táblázat).

A mintákban 22 faj konstans (K V), amelyeknek a fele fásszárú. A szubkonstans (K IV) fajok száma 21. Ezen kívül 35 akcesszórikus (K III), 64 szubakcesszórikus (K II) és 209 akcidens (K I) faj került elő (E1. táblázat (elektronikus mellékletben), 1. ábra). Ennek megfelelően az állandósági kategóriák gyakorisági értékeinek eloszlása U alakú, és minimumát a szubkonstans osztálynál éri el (2. ábra). A konstans fajok közül nyolc azonos a mezőföldi mintákban regisztrált konstans fajokkal.

\section{Karakterfajok aránya}

Mintáinkban a kelet-európai erdőssztyep-erdőkben jellemző fajok (AceriQuercion asszociációcsoport karakterfajai, lásd E1. táblázat, elektronikus mellékletben) közül összesen tizennégy faj fordult elő. Többségüket csupán egy vagy néhány felvételben észleltük. A karakterfajok között állandó faj nem fordult elö, és csak négy faj (Carex michelii, Pulmonaria mollis, Euphorbia epithymoides, Phlomis tuberosa) konstanciája haladta meg a II-es értéket (K III-IV). A leggyakrabban előforduló faj, a Carex michelii, 16 mintában volt megtalálható. A karakterfajok mintánkénti száma tág határok (0-9) között változott.

A kizárólag vagy részben az Aceri-Quercion asszociációcsoportra jellemző karakterfajok csoportrészesedése 1,3\%, ami azonos a szubmediterrán jellegü Orno-Cotinion csoport karakterfajainak csoportrészesedésével. A Mezőföld erdőssztyep tölgyeseihez képest ezek az értékek az Aceri-Quercion esetében alig, míg az Orno-Cotinion esetében számottevően magasabbak (2. táblázat).

A vizsgált állományok fajainak többsége $(38,1 \%)$ a délkelet-európai száraz tölgyesekre (Quercetea pubescentis-petraeae s. 1.) jellemző. Ez az érték a Mezőföld állományaiban becsült értéknél magasabb. Az európai lomberdők (Querco-Fagetea s. 1.) karakterfajainak csoportrészesedése (14,7\%) szintén meg-

1. táblázat. Az Észak-Mezőföld felnyíló, és a Mezőföld tatárjuharos-tölgyeseiben észlelt fajdiverzitási értékek, és a különbségek statisztikai szignifikanciája a t-eloszlás alapján.

Table 1. Species diversity values in the samples from the Northern Mezőföld and the Mezőföld and the probability of their difference by chance under the t distribution. (1) Total species richness; (2) Species number per sample; (3) Number of shrub species per sample ; (4) Number of herbaceous species per sample.

\begin{tabular}{lccc}
\hline & $\begin{array}{c}\text { Észak-Mezőföld } \\
(\mathrm{n}=20)\end{array}$ & $\begin{array}{c}\text { Mezöföld } \\
(\mathrm{n}=20)\end{array}$ & $\mathrm{P}$ \\
\hline Összesített fajszám (1) & 351 & 327 & n.a. \\
Mintánkénti fajszám (2) & 93,9 & 89,7 & 0,469 \\
Cserjék fajszáma / minta (3) & 12,0 & 10,0 & 0,039 \\
Lágyszárúak fajszáma / minta (4) & 75,4 & 74,0 & 0,806 \\
\hline
\end{tabular}


haladja a mezőföldi mintákban tapasztalt értéket, míg a sorrendben második szárazgyep (Festuco-Brometea s. 1.) fajok értéke szinte azonos a mezőföldi állományokban becsült értékkel. Figyelemre méltó, hogy bár csak alacsony gyakorisággal, de előfordulnak az Aremonio-Fagion csoportra jellemző fajok is, amelyek a mezőföldi állományokból teljes mértékben hiányoztak.

A mezőföldi mintákban tapasztaltaktól eltérően a főbb jellemző asszociációcsoportok karakterfajainak csoportrészesedése nem mutat fokozatos emelkedést a szubmediterrán száraz bokorerdőktől (Orno-Cotinion s. 1.) a mezofil lomberdőkön (Fagion sylvaticae s. 1.) át a sztyepekig (Festucion rupicolae s. 1.), minthogy a száraz bokorerdők karakterfajainak csoportrészesedése itt már azonos az Aceri-Quercion karakterfajok csoportrészesedésével (3. ábra).

A bolygatást illetve zavarást jelző Chenopodio-Scleranthea s. 1. karakterfajainak csoportrészesedése $12,9 \%$, csoporttömege pedig 3,1\%. Az adventív fajok csoportrészesedése 1,6\%. Mindkét esetben az értékek alacsonyabbak, a Chenopodio-Scleranthea esetében számottevő mértékben, a mezőföldi mintákból becsült értékeknél (4. ábra).

\section{Flóraelemek aránya}

Az Észak-Mezőföld tölgyeseit - hasonlóan a Mezőföld tatárjuharos-tölgyeseihez - a legnagyobb arányban eurázsiai elterjedésü fajok alkotják. Ezeket

2. táblázat. A főbb szüntaxonok karakterfajainak csoportrészesedés és csoporttömeg értékei az észak-mezőföldi (ÉMf) és mezőföldi (Mf) mintákban.

Table 2. Mean percentages of summed frequencies and those weighted by cover values of the characteristic species of selected syntaxa in the samples from the Northern Mezöföld (ÉMf) and the Mezőföld proper (Mf). (1): Syntaxa; (2) Relative frequency (\%); (3) Relative frequency weighted with cover values (\%).

\begin{tabular}{lcccc}
\hline \multirow{2}{*}{ Szüntaxon (1) } & \multicolumn{3}{c}{ Csoportrészesedés\% (2) } & \multicolumn{2}{c}{ Csoporttömeg\% (3) } \\
\cline { 2 - 5 } & ÉMf & Mf & ÉMf & Mf \\
\hline Aceri tatarici-Quercion & 1,3 & 1,2 & 2,0 & 1,9 \\
Orno-Cotinion & 1,3 & 0,3 & 7,1 & 0,0 \\
Fagion sylvaticae s. 1. & 2,6 & 1,7 & 3,0 & 1,8 \\
Aremonio-Fagion & 0,3 & 0,0 & 0,5 & 0,0 \\
Festucion rupicolae s. 1. & 3,9 & 3,7 & 1,3 & 1,0 \\
Quercetalia cerridis s. 1. & 2,4 & 2,2 & 3,4 & 2,5 \\
Orno-Cotinetalia s. 1. & 1,3 & 0,3 & 7,1 & 1,3 \\
Fagetalia sylvaticae s. 1. & 5,3 & 3,1 & 5,2 & 6,6 \\
Festucetalia valesiacae s. 1. & 12,3 & 12,3 & 3,7 & 3,3 \\
Quercetea pubescentis-petraeae s. 1. & 38,1 & 35,2 & 63,8 & 54,5 \\
Querco-Fagetea s. 1. & 14,7 & 12,5 & 21,1 & 25,5 \\
Festuco-Brometea s. 1. & 20,6 & 20,4 & 6,6 & 6,8 \\
\hline
\end{tabular}




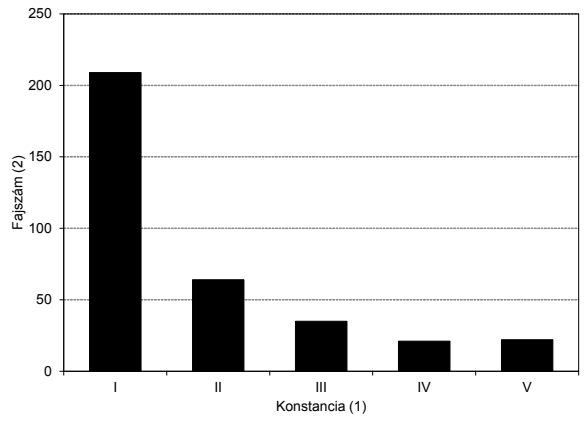

2. ábra. A különböző konstancia osztályokba eső fajok gyakorisági eloszlása az észak-mezöföldi mintákban $(\mathrm{n}=20)$.

Fig. 2. Frequency distribution of species in different constancy classes in the samples from the Northern Mezöföld $(n=20)$. (1) Constancy class; (2) Number of species.

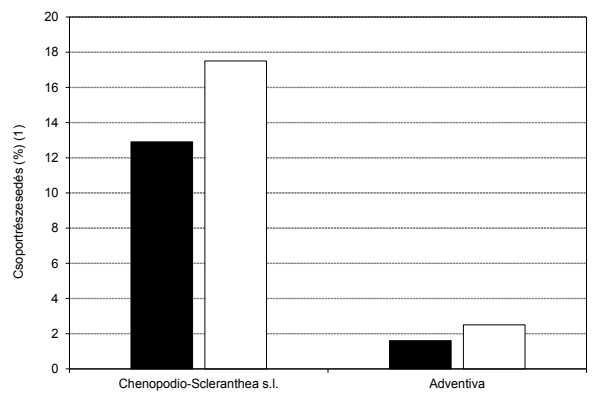

4. ábra. A zavarást-bolygatást jelző Chenopodio-Scleranthea s.l. és az antropogén hatást jelző behurcolt (adventív) fajok százalékos csoportrészesedése az észak-mezőföldi (fekete) és a mezőföldi (fehér) állományokban.

Fig. 4. Per cent proportions of ChenopodioScleranthea s. 1. species and introduced aliens (Adventiva) indicating habitat disturbance and anthropogenic influences, respectively, in the samples from the Northern Mezöföld (black bars) and the Mezöföld proper (white bars). (1) Per cent proportion (\%).

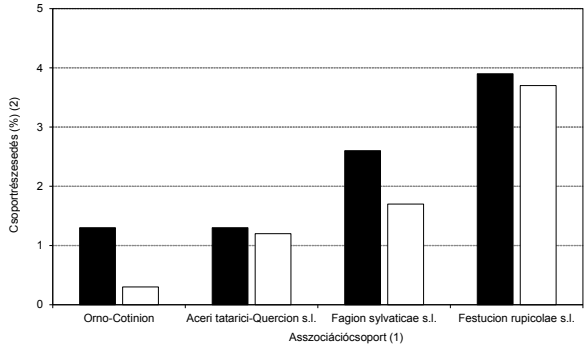

3. ábra. A főbb asszociációcsoportok karakterfajainak százalékos csoportrészesedése az északmezőföldi (fekete) és a mezőföldi (fehér) állományokban.

Fig. 3. Per cent proportions of characteristic species of selected alliances in the samples from the Northern Mezöföld (black bars) and the Mezőföld proper (white bars). (1) Alliance; (2) Per cent proportion (\%).

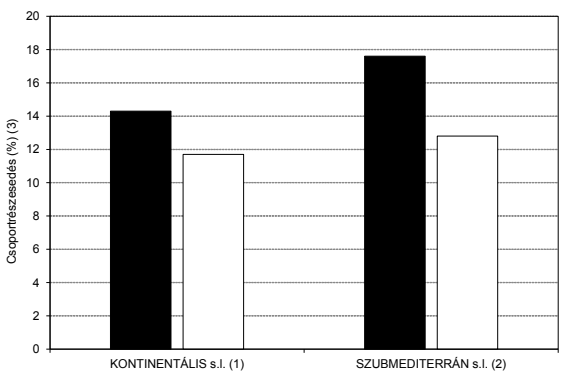

5 ábra. A kontinentális és szubmediterrán elterjedésủ fajok százalékos csoportrészesedése az Észak-Mezőföldön (fekete), valamint a Mezöföldön (fehér).

Fig. 5. Per cent proportions of species with continental (left) and sub-Mediterranean (right) area of distribution in the Northern Mezőföld (black bars) and the Mezöföld proper (white bars). (1) Continental; (2) Sub-Mediterranean; (3) Per cent proportion (\%). 
24\%-os csoportrészesedéssel az európai fajok (EU) követik. A társulás jellegét meghatározó kontinentális elterjedésủ fajok részesedése mindössze 14,3\%, ami azonban még így is meghaladja a Mezőföldön becsült értéket. Ezen belül mind a szủk értelemben vett kontinentális, mind pedig a pontuszi-pannóniai elterjedésü fajok értékei magasabbak a mezőföldi mintákban tapasztaltaknál. A tág értelemben vett szubmediterrán fajok csoportrészesedése az Észak-Mezőföld mintáiban a legmagasabb (17,6\%), amiért leginkább a valódi szubmediterrán fajok magas részesedése a felelös (3. táblázat). Figyelemre méltó a szubmediterrán hatást jelző fajok (Colutea arborescens, Piptatherum virescens, Helleborus dumetorum, Cotinus coggygria, Fraxinus ornus, Laburnum anagyroides) viszonylag nagy száma, ami messze meghaladja a mezőföldi mintákban tapasztalt értéket.

A tág értelemben vett kontinentális fajok csoportrészesedése alatta marad a szubmediterrán fajokéinak, hasonlóan a Mezőföld mintáiban tapasztalthoz. A két érték közti különbség azonban jóval nagyobb az Észak-Mezőföld mintáiban, mint a mezőföldiekben (5. ábra). A főbb flóraelemtípusok rangsorrendje szinte

3. táblázat. A főbb flóraelem típusok százalékos csoportrészesedési értékei az Észak-Mezőföld és a Mezőföld mintáiban.

Table 3. Per cent proportions of the commonest floristic elements in the samples from the Northern Mezöföld and the Mezöföld proper. (1) Floristic elements; (2) Cover-weighted per cent proportions.

\begin{tabular}{lcc}
\hline & \multicolumn{2}{c}{ Csoportrészesedés (\%) (2) } \\
\cline { 2 - 3 } Flóraelemek (1) & $\begin{array}{c}\text { Észak-Mezöföld } \\
(\mathrm{n}=20)\end{array}$ & $\begin{array}{c}\text { Mezöföld } \\
(\mathrm{n}=20)\end{array}$ \\
\hline Eurázsiai s. l. & 29,9 & 37,4 \\
Európai s. 1. & 24,0 & 21,5 \\
Európai & 14,9 & 14,2 \\
Közép-európai & 9,1 & 7,3 \\
Kontinentális s. 1. & 14,3 & 11,7 \\
Kontinentális & 4,9 & 3,9 \\
Szubkontinentális & 0,6 & 0,5 \\
Pontuszi & 8,5 & 7,3 \\
Turáni & 0,2 & 0,0 \\
Szubmediterrán s. 1. & 17,6 & 12,8 \\
Szubmediterrán & 11,3 & 8,6 \\
Kelet-szubmediterrán & 3,0 & 1,5 \\
Balkáni & 2,8 & 2,5 \\
Kaukázusi & 0,2 & 0,2 \\
Kozmopolita & 1,9 & 3,5 \\
Adventív & 1,6 & 2,5 \\
\hline
\end{tabular}


teljesen megegyezik a mezőföldi állományokban tapasztalt sorrenddel (4. táblázat). A flóraelemtípusok gyakorisági eloszlása nem tér el lényegesen a Mezőföld tatárjuharos-tölgyeseiben becsült eloszlástól (6. ábra).

\section{Florisztikai hasonlóság}

A hierarchikus eljárással csoportosított összesen hetven minta két fö csoportra különült el. Az egyik csoportba az általunk gyüjtött húsz minta, továbbá a velencei-hegységi és a mezőföldi minták, a másikba a Vértes melegkedvelő tölgyeseiből származó tíz minta került (7. ábra). A hatvan mintát tartalmazó csoport további két nagyobb alcsoportra vált szét. Ezek egyike a Velencei-hegységből származó mintákat és az észak-mezőföldi minták jelentős részét tartalmazta, míg a másik alcsoportba a mezőföldi minták mellett az Észak-Mezőföld öt fennmaradó mintája (rác-völgyi, tikmony-völgyi, gyúrói) került. Az egyes alcsoportokon belül a minták még további két halmazt képeztek. Az első alcsoporton belül a velencei-hegységi minták váltak el az észak-mezőföldi mintáktól, míg a második alcsoporton belül 14 mezőföldi minta képezte az egyik halmazt, és a fennmaradó hat minta az Észak-Mezőföldről származó öt mintával együtt a másikat.

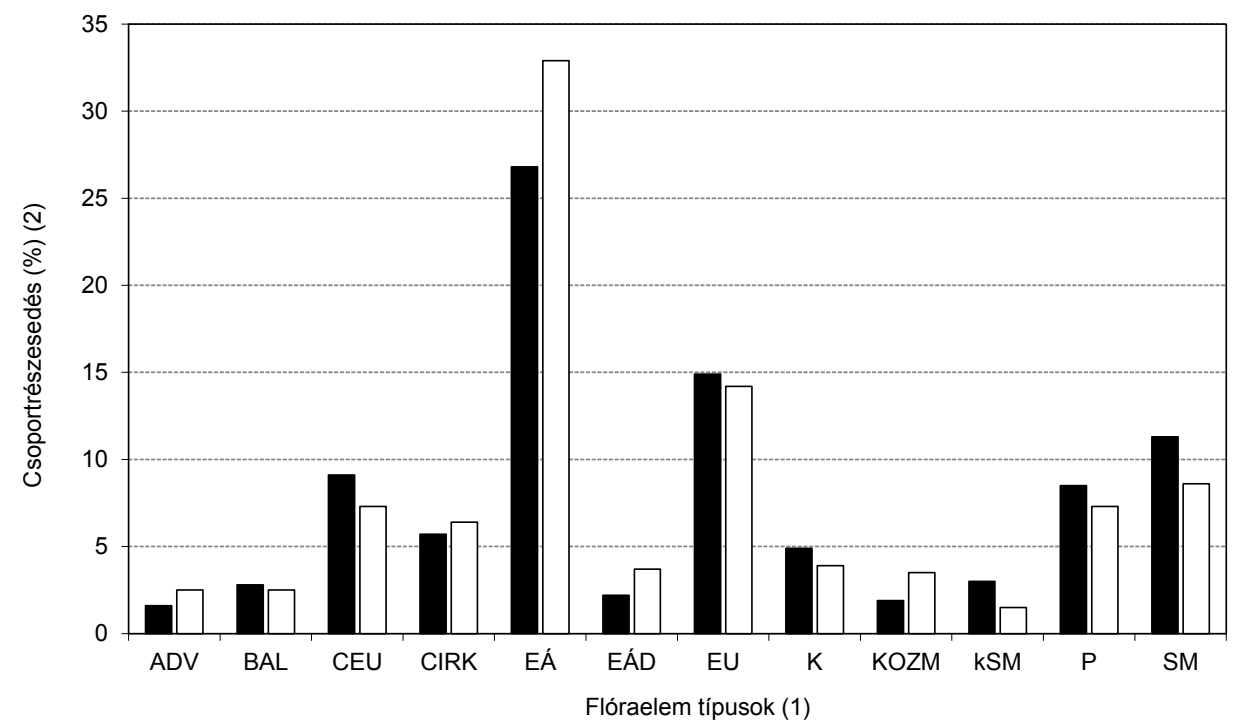

6. ábra. A leggyakoribb flóraelem típusok becsült csoportrészesedéseinek eloszlása az észak-mezőföldi (fekete) és a mezőföldi (fehér) mintákban.

Fig. 6. Distribution of the estimated proportions of the commonest floristic elements in the samples from the Northern Mezőföld (black bars) and the Mezőföld (white bars). (1) Floristic elements; (2) Per cent proportion (\%). 
4. táblázat. A főbb flóraelem típusok csoportrészesedéseinek rangsorrendje az Észak-Mezőföldről és a Mezőföldről származó mintákban.

Table 4. Rank-order of weighted per cent proportions of species with different types of distribution range in the samples from the Northern Mezőföld and the Mezöföld proper. (1) Rank.

\begin{tabular}{ccc}
\hline Rang (1) & Észak-Mezöföld & Mezöföld \\
\hline 1 & EUÁ & EUÁ \\
2 & EU & EU \\
3 & SM & SM \\
4 & CEU & CEU/P \\
5 & P & \\
6 & CIRK & CIRK \\
7 & K & K \\
8 & kSM & EÁD \\
9 & BALK & KOZM \\
10 & EÁD & BALK/ADV \\
11 & KOZM & \\
\hline
\end{tabular}

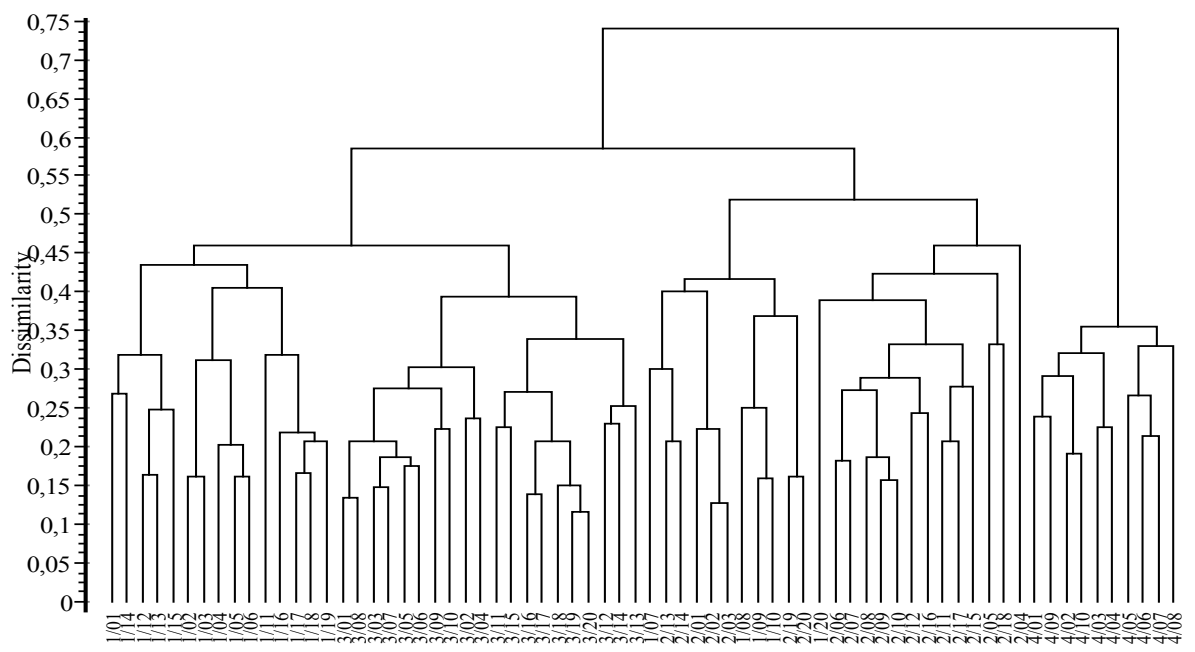

7. ábra. Az Észak-Mezöföld (1/1-20, Horváth et al. ined.), a Mezőföld (2/1-20, LendvaI et al. 2014a) és a Velencei-hegység (3/1-20, LENDVAI et al. 2014b) tatárjuharos-tölgyeseinek, valamint a Vértes melegkedvelő tölgyeseinek (4/1-10, IsÉPY 1970) florisztikai hasonlósága bináris clusterelemzés alapján.

Fig. 7. Cladogram of binary cluster analysis (method: complete link, coefficient: Baroni-Urbani \& Buser) of samples from the Northern Mezöföld (1/1-20, Horváth et al. ined.), the Mezöföld (2/1-20, LendVAi et al. 2014a), the Velence Hills (3/1-20, LendVAi et al. 2014b), and the Vértes Hills (4/1-10, IsÉPY 1970) as an outgroup. 
A fökoordináta-elemzés révén kapott mintaeloszlás a fenti eredményekkel teljes összhangban áll. A teljes mintahalmaz két pontfelhőre különült, amelyek közül a vértesi melegkedvelő tölgyesekből származó mintapontok alkották az egyik, az észak-mezőföldi, mezőföldi, és velencei-hegységi minták pedig a másik pontfelhőt. Utóbbin belül az észak mezőföldi minták köztes helyet foglalnak el a velencei-hegységi és mezőföldi minták pontjai között (8. ábra).

\section{Értékelés}

\section{Elterjedés, termőhelyi viszonyok}

Az Észak-Mezőföldön talált nyílt vagy félig nyílt lombkoronaszintű erdőssztyep állományok előfordulási helyei és a terület erdőinek 18. század végi elterjedése között szoros összefüggés mutatkozik. Nyílt erdőssztyepeket egy kivétellel (Székes-

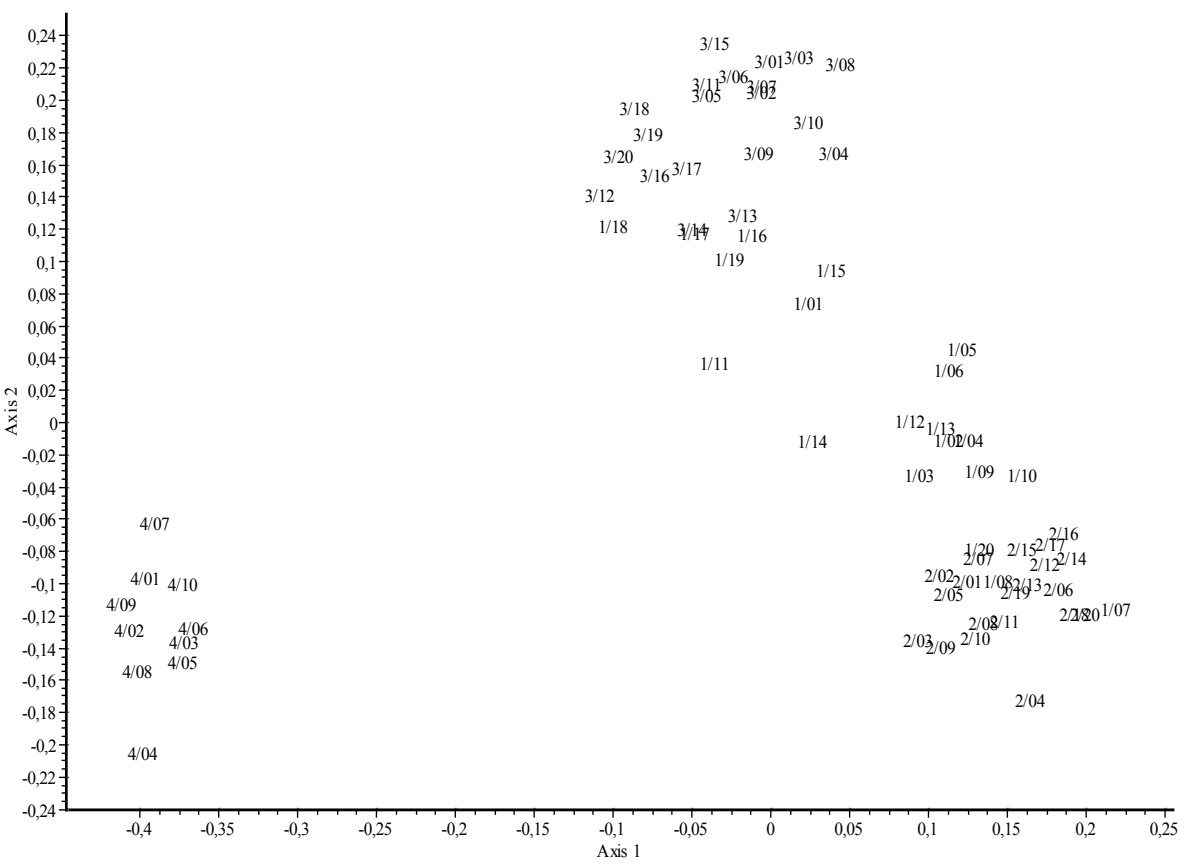

8. ábra. Az Észak-Mezőföld (1/1-20, Horváth et al. ined.), a Mezöföld (2/1-20, LendvaI et al. 2014a) és a Velencei-hegység (3/1-20, LeNDVAI et al. 2014b) tatárjuharos-tölgyeseinek, valamint a Vértes melegkedvelő tölgyeseinek (4/1-10, IsÉPY 1970) fökoordináta-elemzéssel nyert kétdimenziós diagramja.

Fig. 8. Two dimensional binary principal coordinates diagram of samples in this study $(1 / 1-20$, Horváth et al. ined.), the steppe woodlands in the Mezöföld (2/1-20, LendvaI et al. 2014a), the steppe woodlands in the Velence Hills (3/1-20, LendVAI et al. 2014b), and the pubescent oak forests in the Vértes Hills (4/1-10, IsÉPY 1970). 
fehérvár: Rác-völgy) csak ott találtunk, ahol az 1. Katonai Felmérés térképszelvényei még erdőt jeleztek. A későbbi térképek tanúsága szerint ezeken a helyeken, a Gyúró melletti állomány kivételével, még a folyamatos erdőborítás is feltételezhető.

A Rác-völgyben még a 3. Katonai Felmérés térképe sem ábrázol számottevő fás-bokros állományt, így vélhetően ez az állomány egészen újkori keletkezésü. A völgyoldalon tudatos erdőgazdálkodásnak nyoma nincs, az erdőspusztai növényzet teljesen spontán módon regenerálódik. Igazi erdőssztyep-erdőnek is csak jóindulattal tekinthetö, hiszen benne tölgyek egyáltalán nem fordulnak elö, az idegenhonos fajok aránya különösen magas, és mind fafajösszetételét mind a szintek szerkezetét tekintve jelentősen eltér a többi állománytól. A Gyúró melletti állomány esetében viszont a folyamatos erdőborítás nem feltételezhető, mert a 2. Katonai Felmérés térképén a vizsgált területen már nincs erdő. Az általunk vizsgált állomány összefüggő erdőtömb szélén, olyan helyen fordul elő, ahol láthatóan erdőgazdálkodási tevékenység mostanában nem folyt. Itt is feltételezhetően a nyílt erdőssztyep-erdő spontán regenerációja zajlik. Mindez arra utal, hogy az észak-mezőföldi erdőssztyep-tölgyesek túlnyomó része korábbi erdők maradványa, és újraalakulásukra a mai körülmények között föként ott van esély, ahol tervszerủ erdőgazdálkodás nem folyik. Ez eltér a Mezőföld belső részein tapasztaltakkal (LENDVAI et al. 2014a) ahol tatárjuharos-tölgyesek létrejöttére az elmúlt több mint kétszáz év során nem, eltủnésére viszont annál több jel utal.

Az Észak-Mezőföld molyhos tölgyeseinek termőhelyi viszonyai arra utalnak, hogy ezek az erdők ökológiai tekintetben átmeneti helyzetủek az alföldi erdőssztyep és a középhegységi lomberdők között és legalább egy részük már extrazonális megjelenésü. Egy növényzeti öv klímazonális állományának extrazonális megjelenése egy másik, szomszédos növényzeti övön belül nem ismeretlen jelenség a növényföldrajzban (lásd BERG 1950, Soó 1958). Véleményünk szerint az általunk vizsgált terület északi részén, leginkább Alcsút és Gyúró térségében pontosan ez a jelenség figyelhető meg. Úgy véljük, hogy ezek az állományok az alföldi erdőssztyep végső kicsengései a középhegység irányába.

\section{Fajkészlet, diverzitás}

Az Észak-Mezőföld molyhos tölgyeseinek fajkészletében az alföldi erdőssztyep fajai mellett megjelenő középhegységi fajok (Laser trilobum, Sorbus torminalis, Sorbus domestica, Laburnum anagyroides, Helleborus dumetorum, Corydalis intermedia, etc.) előfordulása szintén jelzi a középhegységi erdőkkel fennálló szorosabb florisztikai kapcsolatot.

Feltűnő azonban néhány faj, köztük magának a tatárjuharnak a szinte teljes hiánya a mintáinkból. Ennek oka nem ismert, de vélhetően szerepet játszanak benne a termőhelyi viszonyok. A tatárjuhar ugyanis bár kontinentális elterjedé- 
sü, de nem szárazságtűrő faj. A Duna-medencében elsősorban alacsony magasságban, de legföljebb félszáraz termőhelyeken él. A egyedszámból és sürüségből ítélve optimális élőhelyei az alföldi ártéri keményfás ligeterdők és a zárt homoki és lösztölgyesek, ahol kifejezetten gyakori. A hazai erdőssztyep-erdőkben már csak szórványosan, és lényegesen kisebb állandósággal fordul elő, amint azt Zólyomi eredeti anyaga is mutatja (lásd ZóLYOMI et al. 2013). Elképzelhető, hogy a nyílt és félig nyílt száraz tölgyesek szélsőséges termőhelyei még kevésbé kedvezőek a tatárjuhar számára. Vélhetően hasonló magyarázata lehet annak, hogy a Moldova déli részén található erdőssztyep-tölgyesek egy részéből szintén hiányzik már a tatárjuhar (lásd BoRzA 1937).

\section{Szüntaxonómiai besorolás}

A vizsgált észak-mezőföldi nyílt lombkoronaszintű erdőssztyep-tölgyes állományok társulástani szempontból az alföldi tatárjuharos-tölgyesekhez (Aceri tatarici-Quercetum pubescentis-roboris) állnak a legközelebb, bár már számos vonatkozásban rokon vonásokat mutatnak a Dunántúli-középhegységben elterjedt melegkedvelö molyhos tölgyesekkel (Vicio sparsiflorae-Quercetum pubescentis) is. Ilyen vonás egyebek mellett a legalább részben szubmediterrán elterjedésű fajok (pl. Colutea arborescens, Helleborus dumetorum, Lonicera caprifolium, Sorbus domestica, Piptatherum virescens, Cotinus coggygria, Tilia tomentosa, Laburnum anagyroides, Orchis purpurea) nagyobb számú és gyakran ismétlődő előfordulása, a kocsányos tölgy teljes hiánya, továbbá számos, a erdőssztyep-tölgyesekkel közös, leginkább a száraz tölgyesekre jellemző faj előfordulása.

A helyzet hasonló ahhoz, amivel a Velencei-hegység molyhos tölgyesei kapcsán szembesültünk (LENDVAI et al 2014b). Ott, ahol a két asszociáció egymás közelében fordul elő vagy netán érintkezik is egymással, a kettő elválasztása az általában megszokottnál alaposabb elemzést igényel (lásd FEKETE és Kovács 1982). A faji összetétel önmagában már nem nyújt biztos támpontot a két közösség elkülönítéséhez a fajkészletben mutatkozó nagyfokú átfedés miatt. A melegkedvelő tölgyesek és tatárjuharos-tölgyesek megkülönböztetését azonban az Észak-Mezőföld esetében tovább nehezíti az a tény, hogy itt az Orno-Cotinion fajok csoportrészesedése már nem csak magasabb mind a Mezőföld, mind pedig a Velencei-hegység tatárjuharos-tölgyeseiben becsült értékeknél, hanem azonos az ugyanabban a társulásban észlelt Aceri-Quercion fajok csoportrészesedésével. Az Orno-Cotinion fajoknak az Aceri-Quercion fajokénál magasabb aránya már a melegkedvelö tölgyesek sajátja (Fekete, ex. verb.). E tulajdonságuk alapján a vizsgált észak-mezőföldi állományok már kifejezetten köztes helyzetűek. Melegkedvelö molyhos tölgyeseknek azonban több okból sem tekinthetőek. Egyrészt, a meleg- 
kedvelő tölgyesek számos diagnosztikus faja (Vicia sparsiflora, Carex halleriana, Coronilla emerus, stb.) gyakorlatilag teljes mértékben hiányzik belölük, másrészt pedig a tatárjuharos-tölgyesekben jellemző pontuszi-kontinentális elterjedésű erdőssztyep fajok jelentős része jelen van bennük (Phlomis tuberosa, Ajuga laxmanni, Inula germanica, Acer tataricum, Amygdalus nana, Cerasus fruticosa, Cotoneaster niger, Iris pumila, Hypericum elegans, Serratula radiata, Inula hirta). Különösen érvényes ez a Szár-hegy tatárjuharos-tölgyeseire, amelyet többen (BAUER és Somlyay 2007) is melegkedvelő tölgyesként értelmeztek. Az északmezőföldi minták florisztikai affinitása és ezáltal szüntaxonómiai hovatartozása a sokváltozós elemzések eredményei alapján egyértelmü.

\section{Az állományok szubmediterrán jellege}

Eredményeink azt mutatják, hogy az Észak-Mezőföld erdőssztyep-tölgyesei faji összetételük tekintetében jóval erősebb szubmediterrán jelleget mutatnak, mint a mezőföldiek, és e szempontból a Velencei-hegység tatárjuharos-tölgyeseihez állnak közel (lásd LENDVAI et al. 2014b). Ez összhangban áll ZóLYOMI (1957, 1958) megállapításával, aki a Velencei-hegységben és az Észak-Mezőföldön, illetve a Tétényi-fennsíkon és a Gödöllői-dombság északi részén gyűjtött minták alapján állította fel az ornetosum szubasszociációt annak szubmediterrán jellegére hivatkozva. Feltűnő azonban, hogy ez a szubmediterrán jelleg a Mezőföldön a flóraelemek tekintetében már több mint 25\%-kal kisebb.

Hangsúlyozni kell azonban, hogy ez a szubmediterrán jelleg csupán a Kárpátmedencén, pontosabban a Zólyomi-féle asszociáción belül értelmezhető, és értelmét veszti nagyobb léptékü összehasonlításoknál. Ugyanis a szubmediterrán erdőssztyep (BORZA in LAVRENKo 1970) erdei vegetációján belül még a Dunamedencei szubmediterrán jellegü tatárjuharos-tölgyes (ornetosum) is kifejezetten kontinentális jellegű a tőlünk délre és délkeletre előforduló és sokkal inkább szubmediterrán vonásokat mutató rokon társulásokhoz (Aceri tatarici-Quercetum pedunculiflorae, Aceri tatarici-Quercetum confertae) képest (lásd Zólyomi 1957, PURGER et al. 2014).

Az Észak-Mezőföld tatárjuharos-tölgyeseinek kifejezett szubmediterrán jellegét több tényező is okozhatja. Ez lehet a területen már erősebben érvényesülő szubmediterrán klímajelleg, de pusztán a szubmediterrán flóraelemekben gazdagabb középhegység közelsége is. Ez utóbbi még akkor is az eltérő jellegű flórák bizonyos mértékủ keveredését idézheti elő (az ökológiai optimumtól távoli élőhelyek ismételt és gyakori kolonizációjával), ha azt a makro- és mezoklimatikus feltételek nem indokolják. Részletesebb klímaadatok hiányában nincs módunk e két lehetőséget alaposabban kielemezni. 


\section{Természetességi állapot}

Az Észak-Mezőföld környékének tatárjuharos-tölgyeseiben a bolygatást és zavarást jelző ChenopodioScleranthea s. 1. szüntaxon karakterfajainak és az idegenhonos fajok csoportrészesedési értékei arra utalnak, hogy ezek az állományok a mezőföldieknél természetközelibb állapotúak és bennük az emberi zavarás kisebb mértékben mutatkozik. Ugyanakkor az egyes állományok jelenlegi állapota széles skálán mozog. Több állomány (Nádasdladány: Kasza-völgy; Kőszár-hegy: Szár-hegy; Pátka: Máriamajori-erdő, Nagy-völgy; Zámoly: Csapás-völgy; Alcsút: Csaplári-erdő) kifejezetten természet közelinek tekinthető, míg másokban (Székesfehérvár: Rác-völgy; Pátka: Tikmony-völgy; Gyúró: Homokvételi-dűlő) a gyomok és idegenhonos fajok aránya meglehetősen magas.

Szinte minden állományban megfigyelhető volt a nagyvadak (elsősorban vaddisznó) okozta bolygatás, amely nem csak az eredeti aljnövényzet pusztulását okozta, hanem a jelek szerint teret ad a lágy- és fás szárú gyomfajok sikeres megtelepedésének is. Utóbbit elősegíti a jelenlegi, véghasználaton alapuló erdőgazdálkodási gyakorlat is. Az állományok elszigeteltsége miatt mindez azt vetíti előre, hogy a jelenlegi feltételek között hosszabb távon csak aktív beavatkozással tartható fenn a tájegység tatárjuharos-tölgyeseinek állapota.

\section{Köszönetnyilvánítás}

Köszönetünket fejezzük ki Fekete Gábor akadémikusnak hasznos tanácsaiért, valamint a két névtelen bírálónak a kézirat bírálata során tett kritikai észrevételeikért és a dolgozat minőségét növelő javaslataikért.

\section{Rövidítések}

A1: felső lombkoronaszint, A2: alsó lombkoronaszint, B1: cserjeszint, B2: újulat, C: gyepszint, cs.r.: csoportrészesedés, cs.t.: csoporttömeg, s. l.: sensu lato (tágabb értelemben); S: summa (összeg).

Flóraelemek rövidítése: ADV: adventív, BALK: balkáni, CEU: közép-európai, CIRK: cirkumboreális, EÁ: eurázsiai, EÁD: dél-eurázsiai, EU: európai, K: kontinentális, KOZM: kozmopolita, kSM: kelet-szubmediterrán, SM: szubmediterrán.

Szüntaxonok rövidítése: Ai: Alnion incanae, Alo: Alopecurion pratensis, Ape: Aperetalia, AQ: Aceri tatarici-Quercion, Ar: Artemisietea, AR: Agropyro-Rumicion crispi, ArA: Artemisio-Agropyrion intermedii, Ara: Arrhenatheretea, ArF: ArtemisioFestucetalia pseudovinae, Arn: Arrhenatherion elatioris, Ate: Alnetea glutinosae, Bia: Bidentetea, Bra: Brometalia erecti, Cal: Calystegion sepium, Cau: Caucalidion platycarpos, Che: Chenopodietea, ChS: Chenopodio-Scleranthea, Cp: Carpinenion betuli, CU: Calluno-Ulicetea, Cyc: Cynosurion cristati, CyF: Cynodonto-Festucenion, Des: Deschampsion caespitosae, EP: Erico-Pinetea, Epa: Epilobietea angustifolii, F: Fagetalia sylvaticae, FB: Festuco-Bromea, FBt: Festuco-Brometea, FiC: Filipendulo-Cirsion olera- 
cei, FPe: Festuco-Puccinellietea, FPi: Festuco-Puccinellietalia, Fru: Festucion rupicolae, Fvg: Festucetea vaginatae, Fvl: Festucetalia valesiacae, GA: Galio-Alliarion, GU: Galio-Urticetea, KC: Koelerio-Corynephoretea, Mag: Magnocaricetalia, Moa: Molinietalia coeruleae, MoA: Molinio-Arrhenatherea, MoJ: Molinio-Juncetea, Mon: Molinion coeruleae, NC: Nardo-Callunetea, Nc: Nanocyperion flavescentis, OCa: Orno-Cotinetalia, OCn: Orno-Cotinion, Ona: Onopordetalia, Onn: Onopordion acanthii, Pla: Plantaginetea, Pna: Populenion nigro-albae, PP: Pulsatillo-Pinetea, PQ: Pino-Quercetalia, Prf: Prunion fruticosae, Pru: Prunetalia spinosae, Pte: Phragmitetea, Qc: Quercetalia cerridis, Qfa: Quercion farnetto, QFt: Querco-Fagetea, Qp: Quercion petraeae, Qpp: Quercetea pubescentis-petraeae, Qr: Quercetalia roboris, Qrp: Quercion robori-petraeae, Sea: Secalietea, Sio: Sisymbrion officinalis, Spu: Salicetea purpureae, SS: SedoScleranthetea, TA: Tilio platyphyllae-Acerenion pseudoplatani, TAi: Thero-Airion, Ulm: Ulmenion, US: Urtico-Sambucetea.

\section{Irodalomjegyzék}

BARINA Z. 2004: A Dunántúli-középhegység növényföldrajzának főbb jellemzői. Flora Pannonica 2: 37-55.

BAUER N., SOMLYAY L. 2007: Sysimbrium polymorphum (Murray) Roth és más florisztikai adatok a Nyugat-Mezőföldről. Kitaibelia 12: 52-55.

BeCKING R. W. 1957: The Zürich-Montpellier School of phytosociology. Botanical Review 23: 411-488. http://doi.org/10.1007/bf02872328

Berg L. S. 1950: Natural Regions of the U.S.S.R. The Macmillan Company, New York.

BoRHIDI A. 1993: A magyar flóra szociális magatartás típusai, természetességi és relatív ökológiai értékszámai. Janus Pannonius Tudományegyetem, Pécs.

BORHIDI A. 1995: Social behaviour types, the naturalness and relative ecological indicator values of the higher plants in the Hungarian flora. Acta Botanica Academiae Scientiarum Hungaricae 39: 97-181.

Borhidi A. 2003: Magyarország növénytársulásai. Akadémiai Kiadó, Budapest, 610 pp.

Borhidi A., KeVEY B. 1996: An annotated checklist of the Hungarian plant communities II. In: Borhidi A. (ed.): Critical revision of the Hungarian plant communities. Janus Pannonius University, Pécs, pp. 95-138.

BorzA A. 1937: Cercetări fitosociologice asupra pădurilor Basarabene. Buletinul Grădinii Botanice şi al Muzeului Botanic dela Universitatea din Cluj, XVII(1-2): 1-85.

Bölöni J., MolnÁr Zs., Biró M., Horváth F. 2008: Distribution of the (semi-)natural habitats in Hungary II. Woodlands and shrublands. Acta Botanica Hungarica 50(Suppl.): 107-148. http://dx.doi.org/10.1556/ABot.50.2008.Suppl.6

BRAUn-BlaneUet J. 1964: Pflanzensoziologie (ed. 3.). Springer Verlag, Wien-New York, 865 pp. DiDukh J. P. (ed.). 2009: Zeljona knyiga Ukrainyi. Altyerpresz, Kiiv. pp. 448.

Fe Kete G. 1955: Die Vegetation des Velenceer Gebirges. Annales Historico-Naturales Musei Nationalis Hungarici Series Nova 7: 343-362.

FeKete G., KovÁcs M. 1982: A fóti Somlyó vegetációja. Botanikai Közlemények 69: 19-31.

FeKeTe G., VARga Z. 1999: Tatárjuharos tölgyes (Aceri tatarici-Quercetum roboris). in: BorHIDI A., SÁNTA A. (szerk.) 1999: Vörös könyv Magyarország társulásairól. 2. kötet. Természetbúvár Alapítvány Kiadó, Budapest, pp. 282-285.

Grubov V. I. 2001: Key to the vascular plants of Mongolia. Enfield, New Hampshire. 
HARASZThy L. 2000: Az erdőssztepp: eltűnő örökségünk. WWF füzetek 15: 3-4.

Horváth F., Dobolyi Z. K., Morschhauser T., Lökös L., Karas L., SZerdahelyi T. 1995: Flóra adatbázis 1.2. Vácrátót, 267 pp.

IsÉPY I. 1970: Phytozönologische Untersuchungen und Vegetationskartierung im Südöstlichen Vértes-Gebirge. Acta Botanica Academiae Scientiarum Hungaricae 16 (1-2): 59-110.

KEVEY B. 2008: Magyarország erdőtársulásai (Forest associations of Hungary). Tilia 14: 1-488.

KEVEY B., HirmanN A. 2002: „NS” számítógépes cönológiai programcsomag. In: Aktuális flóra- és vegetációkutatások a Kárpát-medencében V. Pécs, 2002. március 8-10. (Összefoglalók), p. 74.

KIRÁLY G. (szerk.) 2009: Új magyar füvészkönyv. Magyarország hajtásos növényei. Határozókulcsok. Aggteleki Nemzeti Park Igazgatóság, Jósvafö, 616 pp.

Lavrenko E. M. 1970: Provincialnoje razgyelenyije Pricsornomorszko-Kazahsztanszkoj Podoblasztyi sztyepnoj oblasztyi Evrazii. Botanyicseszkij Zsurnal 55: 609-625.

Lavrenko E. M., Karamüseva Z. V., Nyikulina R. N. 1991: Sztyepi Evraziji. Nauka, Leningrad, $146 \mathrm{pp}$.

Lendvai G., Horváth A., Kevey B. 2014a: A Mezőföld tatárjuharos tölgyesei (Aceri tatariciQuercetum pubescentis-roboris Zólyomi 1957). Botanikai Közlemények 101: 145-188.

Lendvai G., Horváth A., Kevey B. 2014b: A Velencei-hegység tatárjuharos tölgyesei (Aceri tatarici-Quercetum pubescentis-roboris Zólyomi 1957). Botanikai Közlemények 101: 189-226.

Mucina L., Grabherr G., Wallnöfer S. 1993: Die Pflanzengesellschaften Österreichs III. Wälder und Gebüsche. Gustav Fischer, Jena-Stuttgart-New York, 353 pp.

Oberdorfer E. 1992: Süddeutsche Pflanzengesellschaften IV. A. Textband. Gustav Fischer Verlag, Jena-Stuttgart-New York, $282 \mathrm{pp}$.

PoDANI J. 2001: SYN-TAX 2000. Computer Programs for Data Analysis in Ecology and Systematics. Scientia, Budapest, $53 \mathrm{pp}$.

Purger D., Lengyel A, Kevey B., Lendvai G., Horváth A, Tomić Z., Csi Ky J. 2014: Numerical classification of oak forests on loess in Hungary, Croatia and Serbia. Preslia, 86: 47-66.

Savulescu T., Nyárády E. J. (eds.) 1952-1976: Flora Republicae Populariae Romanei. vols 1-13. Bucuresti.

Simon T. 1994: A magyarországi edényes flóra határozója. Harasztok és virágos növények. Nemzeti Tankönyvkiadó, Budapest, 2. kiadás.

Siskin B. K., Bobrov J. G. (eds) 1933-1964: Flora SzSzSzR. vols. I-XXX. Izd. Akad. Nauk, Moszkva.

SonNevend I. 2001: Tatárjuharos-lösztölgyes maradványok a Nyugat-Mezőföldön. Kitaibelia 6: 377-380.

Soó R. 1958: Összehasonlító vegetációtanulmányok a Szovjetunió erdős-sztyep övében. Az MTA Biol. Csop. Közlem. 1: 209-222.

Soó R. 1962: Növényföldrajz. Tankönyvkiadó, Budapest, 180 pp.

Soó R. 1964-1980: A magyar flóra és vegetáció rendszertani-növényföldrajzi kézikönyve I-VI. Akadémiai Kiadó, Budapest.

Tutin T. G. et al. (eds.) 1964-1980: Flora Europaea, vols. I-V. University Press, Cambridge.

Zólyomi B. 1957: Der Tatarenahorn-Eichen-Lösswald der zonalen Waldsteppe. Acta Botanica Academiae Scientiarum Hungaricae 3: 401-424.

Zólyomi B. 1958: Budapest és környékének természetes növénytakarója. In: PÉcsi M. (szerk.): Budapest természeti képe. Akadémiai Kiadó, Budapest, pp. 511-642.

ZóLYomi B. 1959: Beszámoló az MTA Botanikus kertje és Geobotanikai Laboratóriuma munkájáról II. Magyar Tudományos Akadémia Biológiai Csoportjának Közleményei 3: 51-59.

Zólyomi B. 1989: Természetes növénytakaró, 1: 1500 000. In: Pécsi M. (szerk.) Magyarország Nemzeti Atlasza. Kartográfiai Vállalat, Budapest, p. 89. 
Zólyomi B., Horváth A., Kevey B., Lendvai G. 2013: Steppe woodlands with Tatarian maple (Aceri tatarici-Quercetum pubescentis-roboris) on the Great Hungarian Plain and its neighborhood. An unfinished synthesis with supplementary notes. Acta Botanica Hungarica 55: 167-189. https://doi.org/10.1556/abot.55.2013.1-2.11

Elektronikus melléklet: E1-E2. táblázatok.

Electronic supplement: Tables E1-E2.

E1. táblázat. Az Észak-Mezőföldön felvett húsz cönológiai felvétel összesített táblázata.

Table E1. Synoptic table of the twenty phytosociological samples collected in the Northern Mezőföld.

E.2. táblázat. Az Észak-Mezőföldön felvett húsz cönológiai felvétel adatai.

Table E2. Relevés' data for the twenty phytosociological samples collected in the Northern Mezőföld.

\section{Steppe woodlands with Tatarian maple (Aceri tatarici-Quercetum} pubescentis-roboris Zólyomi 1957) in the Northern Mezöföld and adjacent areas, Hungary

\section{A. HORVÁTH ${ }^{1}$, B. KEVEY ${ }^{2 *}$, G. LENDVAI ${ }^{3}$, Gy. SIMON ${ }^{4}$, I. SONNEVEND ${ }^{5}$}

${ }^{1}$ MTA Centre for Ecological Research, Institute of Ecology and Botany, Alkotmány u. 2-4, H-2163 Vácrátót; horvath.andras@okologia.mta.hu

${ }^{2}$ University of Pécs, Department of Ecology, Ifjúság útja 6,H-7624 Pécs; keveyb@ttk.pte.hu

${ }^{3}$ Ady E. út 162, H-7000 Sárbogárd; gaborlendvai@hotmail.com ${ }^{4}$ Széchenyi u.35., H-8000 Székesfehérvár; tepuisimon@gmail.com ${ }^{5}$ Lóczi L. u. 5/G, H-8200 Veszprém; sonnevend.imre@chello.hu

Accepted: 20 April 2017

Key words: forest steppe on loess, Great Hungarian Plain, multivariate comparisons, syntaxonomy.

* Corresponding author. 
As the third part of a series describing and analyzing steppe woodlands in the westernmost part of the Great Hungarian Plain, the Mezöfold, Hungary, this paper presents the major findings of the analysis of 20 phytosociological samples collected in the northern part of our study area, closest to the Central Transdanubian Mountain Range.

We found steppe woodland remnants in this area mostly at locations that were indicated as forested on historical maps drawn in the fourth quarter of the 18 th century. These stands were highly similar to one another in structure (layers, canopy openness, height), species composition, and ecological and phytogeographical features. We compared the phytosociological parameters of these samples to those from the Mezöföld. The proportion of characteristic species of selected syntaxa were by and large similar between the two locations, with the notable difference in the proportions of Fagion s. 1. and Fagetalia s. 1. and OrnoCotinion and Orno-Cotinetalia s. 1. with excess values in the samples from the Northern Mezőföld, and also Chenopodio-Scleranthea s. 1. with an excess value in the samples from the Mezöföld. The proportion of Orno-Cotinion species substantially exceeded that of Aceri-Quercion s. 1. as opposed to the samples from the Mezőföld.

The distribution of proportions of different floristic elements was also similar to that in the Mezöfolld except for the species with sub-Mediterranean s. 1 . range of distribution. Their value was notably higher than that in the Mezöföld. Multivariate comparisons revealed strong similarity to the samples from both, the Velence Hills and the Mezöföld, whereas they were expressly distinct from pubescent oak forests (Vicio sparsiflorae-Quercetum pubescentis), a closely related community of the Vértes Hills.

We concluded that the studied stands most likely represent the sub-Mediterranean variant of steppe woodlands with Tatarian maple sensu Zólyomi (Aceri tatarici-Quercetum pubescentis-roboris ornetosum). These steppe woodlands exhibit a much more pronounced sub-Mediterranean character in species composition than the ones in the Mezöföld, and, as such, are more closely related to the steppe woodland remnants in the neighboring Velence Hills. 